Original Research Paper

\title{
Pembangunan Digitasi Pohon Manggis di Desa Karang Bayan (Studi Kasus Kelompok Tani Konta Nyembao)
}

\author{
Kurniawan Yuniarto ${ }^{1}$, Selly Oktavianti ${ }^{2}$, Edwin Eka Hartono ${ }^{3}$, M. Alfi Ashabana ${ }^{4}$, Ahmada Mu'ammar \\ Dony Firmansyah ${ }^{6}$
}

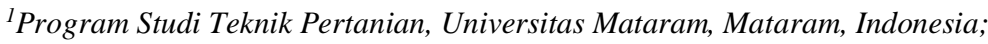

${ }^{2}$ Jurusan Teknik Sipil, Universitas Mataram, Mataram, Indonesia;

${ }^{3}$ Program Studi Sosiologi, Universitas Mataram, Mataram, Indonesia;

${ }^{4}$ Jurusan Teknik Elektro, Universitas Mataram, Mataram, Indonesia;

${ }^{5}$ Jurusan Teknik Mesin, Universitas Mataram, Mataram, Indonesia;

${ }^{6}$ Program Studi Manajemen, Universitas Mataram, Mataram, Indonesia;

https://doi.org/10.29303/jpmpi.v3i2.907

Sitasi: Yuniarto, K., Oktavianti, S., Hartono, E. E., Ashabana, M. A., Mu'ammar, A., \& Firmansyah, D. (2021). Pembangunan Digitasi Pohon Manggis di Desa Karang Bayan (Studi Kasus Kelompok Tani Konta Nyembao). Jurnal Pengabdian Magister Pendidikan IPA, 4(3)

Article history

Received: 22 Juli 2021

Revised: 31 Juli 2020

Accepted: 28 Agustus 2021

*Corresponding Author: Kurniawan Yuniarto, Program Studi Teknik Pertanian, Universitas Mataram, Mataram, Indonesia;

Email:

Kurniawan2006@unram.ac.id
Abstract: Revolusi 4.0 dan perkembangan sosial 5.0 menuntut peningkatan efisiensi dalam aktivitas usaha di berbagai sektor. Pertanian termasuk salah satu sektor strategis yang dituntut untuk melakukan pembaruan baik di agribisnis maupun agroindustri. Terkait sosial 5.0, desa menjadi salah satu unsur utama dalam menggerakkan bidang agribisnis sehingga memerlukan diseminasi akses terhadap pasar dalam rangka perdagangan komoditas yang fair dan transparan. Kegiatan pengabdian ini bertujuan untuk mendukung pelaksanaan tata niaga manggis dalam akses pasar secara online di kelompok tani manggis Desa Karang Bayan, Kecamatan Lingsar, Kabupaten Lombok Barat. Metode pelaksanaan dengan partisipatif mitra binaan yang di dampingi dengan mengumpulkan data sebaran dan kapasitas produksi manggis di kelompok Konta Nyembao. Pengolahan data dengan menggunakan aplikasi ArcMAP untuk memperoleh informasi spasial dan atribut kondisi perkebunan manggis di kelompok tani Konta Nyembao, Karang Bayan, Lingsar, Lombok barat. Luaran yang dihasilkan adalah sistem informasi pertanian manggis kelompok tani Konta Nyembao berupa distribusi pohon manggis sebanyak 1.415 pohon dalam sebaran luas penanaman 10,84 Ha. Potensi produksi manggis yang dapat dihasilkan sekitar 41,5 ton per musim manggis.

Keywords: Akses manggis; Peta; Society 5.0

pengaturan kebutuhan air, nutrisi, periode penanaman, waktu pemanenan dan pengaturan kelembaban lingkungan pertumbuhan tanaman buah maupun sayur. Selain itu, keberadaan data digital di dalam sistem pertanian dapat juga ditujukan dalam memperkuat rantai pasok ketahanan pangan melalui bangunan informasi ketersediaan sumberdaya akses komoditas pertanian tersebut dan mendukung dalam pengambilan suatu kebijakan agribisnis tertentu.

Membangun digitasi akan memberikan keuntungan terhadap mendukung rantai pasok dan 
nilai komoditas pertanian. Dampak kepada petani adalah kepemilikan sumber data terkait kesiapan komoditas untuk menembus pasar baik online maupun offline. Selanjutnya, bagi pelaku agribisnis seperti konsumen dan pengepul akan mendapatkan informasi komoditas pertanian dalam mengembangkan rantai bisnisnya. Komunikasi bisnis antara petani sebagai penyedia komoditas dan pihak eksternal (konsumen atau pengepul) akan terfasilitasi lebih cepat dan akurat dengan keberadaan data komoditas terutama dengan adanya paket digitasi sumber daya komoditas pertanian secara online.

Bangunan digitasi pertanian tidak lepas dengan kondisi pertanian di sektor hulu (on farm). Langkah awal dalam digitasi pertanian adalah mengumpulkan data-data objek pertanian pada tingkat tempat sumber produksi pertanian tersebut berada. Pemetaan sumberdaya pertanian adalah langkah umum dalam membangkitkan sumber data dalam digitasi pertanian dengan mengumpulkan data-data berupa ruang (spatial) dan atribut. Pemanfaatan teknik pemetaan pertanian untuk membangun digitasi pemetaan pada bidang pertanian digunakan untuk riwayat kekeringan dan dampaknya terhadap produksi pertanian di Tunisia (Ben Abdelmalek \& Nouiri, 2020). Pemetaan kapasitas produksi bahan pangan lokal di Kanada (Morrison et al., 2011), pemetaan sumber air tanah di Mesir (Elbeih, 2015), pemetaan spasial pertanian rakyat di Italia (Pulighe \& Lupia, 2016), pemetaan geospasial buah dan sayur di Boston, USA (Saha \& Eckelman, 2017).

Memanfaatkan hasil digitasi pertanian akan terwujudkan satu paket sistem informasi pertanian komoditas tertentu yang spesifik, strategis atau unggulan yang diproduksi suatu kelompok usaha tani masyarakat. Pembangunan sistem informasi pertanian dengan memanfaatkan data kewilayahan dapat dicapai melalui instrumen yang disediakan aplikasi sistem informasi geografis (SIG). SIG pada dasarnya merupakan gabungan dari tiga unsur pokok yaitu: sistem, informasi dan geografis (Manongga dkk, 2009). Kelebihan dari SIG untuk membangun digitasi data dapat bekerja dengan cara menggabungkan antara unsur peta (geografis) dan informasi tentang peta tersebut (data atribut) sehingga dapat mendukung dalam mengolah, memanipulasi, analisis, memperagakan dan menampilkan data spasial untuk menyelesaikan perencanaan, mengolah dan meneliti permasalahan.
Tujuan dari pengabdian ini adalah pendampingan dalam digitasi data manggis di kelompok Konta Nyembao, desa Karang Bayan, Kecamatan Lingsar, Kabupaten Lombok Barat. Paket digitasi data manggis diolah lebih lanjut menjadi sistem informasi pertanian distribusi pohon manggis dan proyeksi kapasitas produksi buah manggis di kelompok tani mitra.

\section{Metode}

Pelaksanaan kegiatan pengabdian dengan target pembangunan sistem informasi pertanian manggis kelompok tani Konta Nyembao di laksanakan pada bulan Juni sampai Agustus 2021. Lokasi di lahan perkebunan manggis kelompok tani yang terdiri atas 40 atau dari total lahan milik anggota sejumlah 32 orang.

\section{Bahan dan Alat}

Alat Bahan yang digunakan untuk membangun sistem informasi pertanian meliputi: lahan perkebunan dan pohon manggis. Alat yang digunakan berupa instrumen global position system (GPS) Garmin 60CSX dan Garmin 62S untuk merekam titik koordinat di lapangan, meteran panjang $2 \mathrm{~m}, 50 \mathrm{~m}$ dan $100 \mathrm{~m}$ untuk mengukur diameter pohon manggis dan jarak antar pohon, buku catatan untuk menulis posisi atau titik pohon, kamera telepon genggam untuk merekam kondisi pohon dan lahan, google earth sebagai basemap wilayah dusun atau desa dan program komputer ArcGIS 10.6 untuk mengolah data atribut dan spasial.

\section{Prosedur Pelaksanaan}

Pelaksanaan kegiatan pembangunan sistem informasi pertanian manggis di desa Karang Bayan, Lingsar, Lombok Barat mengikuti langkah sebagai berikut:

1. Kalibrasi GPS untuk memastikan bahwa kemampuan pindai satelit bisa lebih dari 5 (lima) satelit.

2. Membuat batas peta lahan manggis per anggota petani sebagai data spasial dengan cara menitik batas-batas lahan yang disampaikan pemilik lahan.

3. Membuat titik-titik pohon manggis yang tersebar di lahan sebagai data atribut. 
4. Pengolahan data spasial, memasukkan data yang disimpan oleh GPS untuk dibuat poligon menggunakan program ArcMAP.

5. Pengolahan data atribut, properties dari manggis diolah menggunakan worksheet atau tabel di dalam program Ms-Excel 2019.

6. Merubah semua file yang berisi data atribut dan spasial menjadi versi extension "shp".

7. Penggabungan menjadi satu sistem pertanian manggis.

Pelaksanaan kegiatan pengabdian dengan target pembangunan sistem informasi pertanian manggis kelompok tani Konta Nyembao di laksanakan pada bulan Juni sampai Agustus 2021. Lokasi di lahan perkebunan manggis kelompok tani yang terdiri atas 40 atau dari total lahan milik anggota sejumlah 32 orang.

\section{Hasil dan Pembahasan}

\section{Profil Kelompok Tani Manggis Konta Nyembao}

Karang Bayan memiliki 1 (satu) kelompok petani manggis yaitu Konta Nyembao. Kelompok tani ini berdiri sejak 07 Mei 2007 yang beranggotakan 23 orang termasuk ketua, sekretaris dan bendahara. Para petani manggis yang tergabung di dalam kelompok Konta Nyembao menggarap lahan perkebunannya milik sendiri dan bukan merupakan lahan hutan kemasyarakatan (HKm) sehingga tidak memiliki potensi konflik dengan eksternal kelompok.

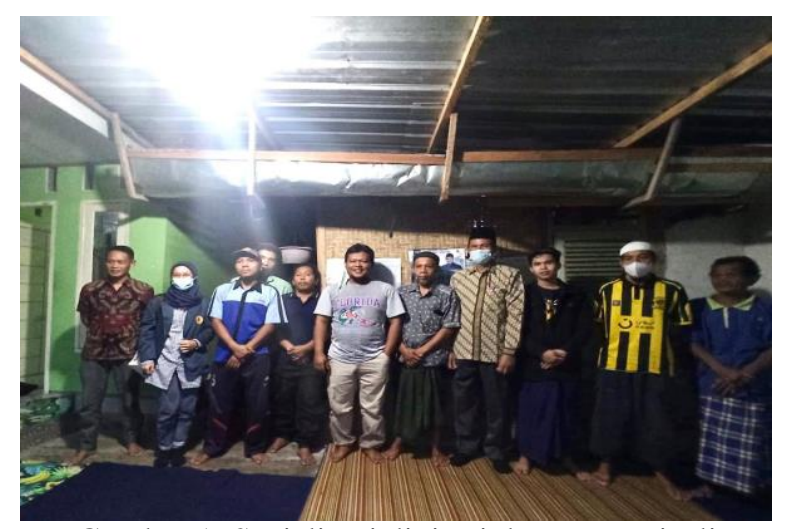

Gambar 1. Sosialisasi digitasi data manggis di kelompok tani Konta Nyembao

Kelompok tani manggis Konta Nyembao melakukan pertemuan tidak rutin. Pertemuan biasa dilakukan apabila ada acara tertentu seperti bantuan sarana produksi pertanian dari dinas pertanian
Lombok Barat atau ada kegiatan yang melibatkan penyuluh lapangan UPTD Lingsar. Kegiatan alih pengetahuan dan teknologi untuk kelompok tani Konta Nyembao masih sangat terbatas sehingga adanya tambahan wawasan perkembangan budidaya ataupun tataniaga manggis belum banyak tersampaikan.

Hasil produksi manggis dijual langsung ke pengepul luar yang telah memiliki hubungan dagang sejak puluhan tahun lalu. Pola penjualan hasil panen anggota kelompok secara sendirisendiri dan belum ada tata kelola bagian dari hasil penjualan untuk menjadi aset atau inventaris kelompok. Penguatan kelembagaan kelompok dan sumberdaya manusia untuk mengembangkan tataniaga manggis masih belum dilakukan.

\section{Pembangunan Database Manggis}

Peran database komoditas pertanian sangat vital dalam mendukung tata niaga manggis pada tingkat hulu. Pembuatan digitasi data manggis yang dimiliki oleh kelompok tani Konta Nyembao dengan membangun data spasial dan atribut memiliki peran strategis dalam mendukung bangunan sistem informasi pertanian modern. Tim database melakukan pengumpulan data seperti tampak pada gambar berikut.

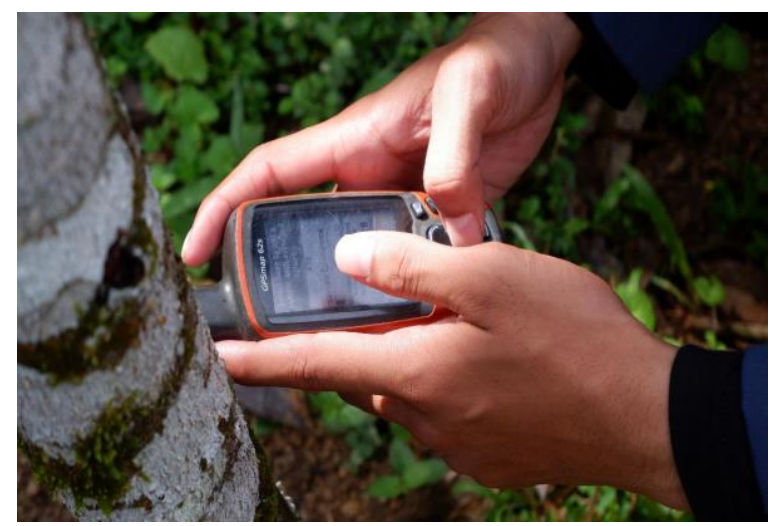

Gambar 2. Pengambilan koordinat pohon manggis

Pohon manggis diambil koordinatnya menggunakan GPS untuk memperoleh lokasi tumbuhnya. Proses pengambilan titik kurang lebih 5 menit sampai dengan kesalahan pembacaan titik oleh satelit dapat diperkecil atau akurasi tinggi. Setiap lokasi tumbuhnya manggis yang tersebar pada lahan petani kelompok Konta Nyembao disimpan dalam bentuk koordinat sebaran pohon manggis. Hasil titik-titik lokasi pohon manggis 
dalam bentuk koordinat ini akan menjadi bagian atribut data yang dibangun dalam sistem informasi pertanian. Selain itu, data atribut yang ditambahkan adalah dimensi dari pohon manggis seperti pada gambar 3. Data atribut merupakan sebuah data yang menjelaskan dari sebuah objek yang dapat berwujud informasi foto, numerik, narasi, dan lain sebagainya (Maulana dkk., 2020).

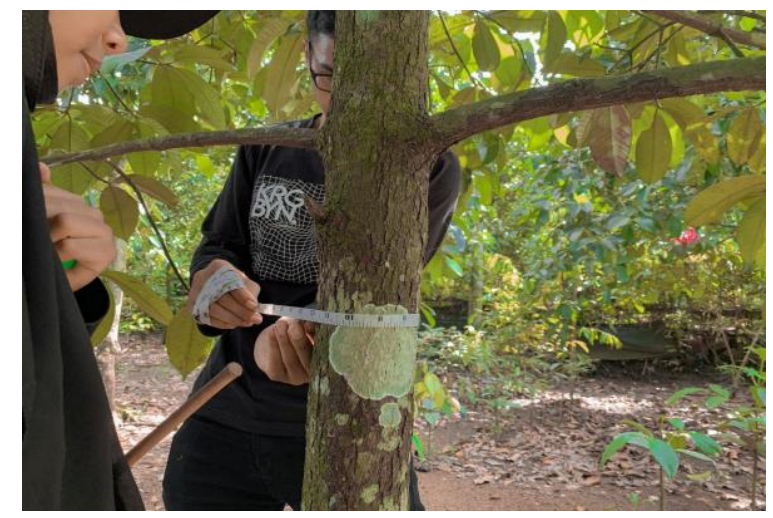

Gambar 3. Pengukuran diameter manggis

Diameter pohon manggis diukur untuk membangun data atribut mewakili kapasitas produksi manggis per pohon. Berdasarkan informasi dari petani, kemampuan produksi manggis ditentukan oleh umur pohon dan dalam kegiatan ini terwakili oleh diameter dari pohon manggis. Tim melakukan klasifikasi dari penyampaian petani antara hubungan diameter pohon dengan kapasitas produksinya dalam tabel berikut.

Tabel 1 Klasifikasi Manggis berdasarkan diameter batang

\begin{tabular}{cccc}
\hline No. & Diameter $(\mathrm{cm})$ & Kelas & Produksi $(\mathrm{kg})$ \\
\hline 1 & $0-20$ & $\mathrm{~A}$ & 0 \\
2 & $21-26$ & $\mathrm{~B}$ & 6 \\
3 & $27-30$ & $\mathrm{C}$ & 12 \\
4 & $31-35$ & $\mathrm{D}$ & 24 \\
5 & $36-40$ & $\mathrm{E}$ & 30 \\
6 & $>40$ & $\mathrm{~F}$ & 50 \\
\hline
\end{tabular}

Sumber: Penyampaian dari petani pemilik lahan

Pembuatan kelas pada Tabel 1 berfungsi untuk memudahkan dalam pembuatan kategori manggis antara yang produktif dan belum produktif serta kapasitas produksinya. Pendataan sebaran manggis (jumlah tersebar dan diameter) selama ini belum pernah terdata oleh pemilik kebun manggis di kelompok Konta Nyembao. Hasil pendataan ini memungkinkan mengetahui atau mengukur aset pohon manggis yang dimiliki oleh para petani yang tergabung di kelompok. Hal lain yang dapat diperoleh adalah memungkinkan sebagai bahan dasar untuk menghitung pohon manggis yang telah mampu berproduksi (aktif berproduksi) dan belum mampu berproduksi. Petani akan memiliki kesempatan dalam memudahkan dan memberikan perhatian terhadap pohon manggis yang belum berproduksi supaya tetap tumbuh dengan perawatan yang baik mengikuti protokol good agriculture practice (GAP).

\section{Sistem Informasi Manggis Konta Nyembao}

Data digital yang bersifat kewilayahan dapat dibangun melalui pendekatan secara spasial dan atribut. Perkembangan teknologi digital sangat besar peranannya dalam perkembangan penggunaan SIG dalam berbagai bidang (Wowor, 2013). Keberadaan manggis yang dikelola oleh kelompok Konta Nyembao dirangkum dalam bangunan sistem informasi pertanian yang terwakili oleh keberadaan informasi data spasial dan atribut. Berikut ini hasil pengembangan sistem informasi pertanian manggis pada kelompok Konta Nyembao.

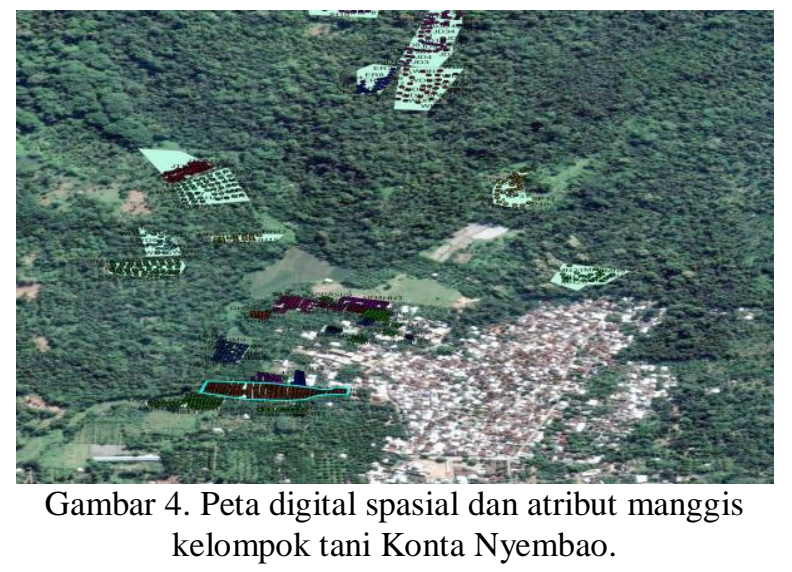

Berdasarkan gambar 3, sebaran pohon manggis yang tumbuh di wilayah lahan petani dapat dipetakan dengan aplikasi ArcGIS 10.6. Sebaran manggis dalam data digital ini dapat menjadi sumber informasi yang menjelaskan atribut seperti tingkat densitas atau distribusi pohon, jumlah pohon dan luas lahan yang dimiliki oleh petani. Hasil analisis spasial dan atribut pohon manggis diperoleh informasi data lahan kepemilikan kelompok Konta Nyembao seluas 10,84 Ha dan jumlah pohon manggis 1415 pohon. 
Digitasi data yang telah dikembangkan pada kelompok Konta Nyembao ini memberikan keleluasaan dalam menampilkan distribusi pohon berdasarkan diameternya juga. Informasi jumlah pohon yang telah mampu berproduksi dapat terukur dengan akurat. Berdasarkan hasil pengolahan data yang ditampilkan pada gambar 4, jumlah pohon manggis tumbuh di lahan milik kelompok paling banyak dengan ukuran diameter $0-20 \mathrm{~cm}$ sebanyak $21 \%$ dan paling sedikit ukuran diameter lebih dari $40 \mathrm{~cm}$ dengan sebaran sebanyak 11,23\%. Estimasi produksi manggis yang dihasilkan oleh kelompok Konta Nyembao dapat mencapai lebih dari 41 ton untuk periode musim manggis per tahun.

\section{Sebaran produksi manggis}

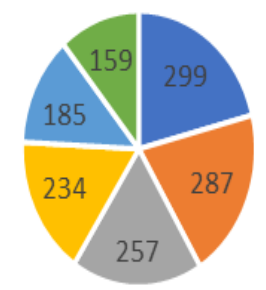

- $0 \mathrm{~kg}=6 \mathrm{~kg}=12 \mathrm{~kg}=24 \mathrm{~kg}=30 \mathrm{~kg}=50 \mathrm{~kg}$

Gambar 4. Peta informasi sebaran produksi manggis

\section{Kesimpulan}

Data-data tersebut memiliki peran strategis dalam mendukung bangunan sistem pertanian modern, dimana memungkinkan untuk mengetahui atau mengukur aset pohon manggis yang dimiliki oleh para petani yang tergabung dalam kelompok tani Konta Nyembao. Kelompok tani Konta Nyembao membantu secara aktif dalam proses digitasi manggis dengan memberikan informasi detail untuk bangunan data spasial dan atribut pohon manggis. Kumpulan data spasial dan atribut dapat digunakan untuk memberikan informasi terkait penggunaan lahan untuk budidaya manggis dan terkumpulnya informasi detail dari atribut manggis yang terwakili oleh diameter pohon. Digitasi kebun manggis kelompok Konta Nyembau memiliki cakupan luas $10.68 \mathrm{Ha}$ dan tertanam 1.415 pohon manggis dengan variasi umur atau diameter pohon. Sistem informasi pertanian manggis yang terbangun memudahkan dalam memperkirakan kapasitas dan sebaran produksi manggis yang dimiliki oleh anggota kelompok tani.

\section{Ucapan Terima Kasih}

Penulis mengucapkan terima kasih kepada kelompok tani Konta Nyembao, tim KKN Tematik Universitas Mataram di desa Karang Bayan, LPPM Universitas Mataram, Kampung Berseri Astra menyelesaikan kegiatan pengabdian ini.

\section{Daftar Pustaka}

Ben Abdelmalek, M., \& Nouiri, I. 2020. Study of trends and mapping of drought events in Tunisia and their impacts on agricultural production. Science of the Total Environment. vol 734.

Elbeih, S. F. (2015). An overview of integrated remote sensing and GIS for groundwater mapping in Egypt. Ain Shams Engineering Journal. vol 6(1), hal https://doi.org/10.1016/j.asej.2014.08.008

Morrison, K. T., Nelson, T. A., \& Ostry, A. S. (2011). Methods for mapping local food production capacity from agricultural statistics. Agricultural Systems. vol 104(6), hal 491-499. https://doi.org/10.1016/j.agsy.2011.03.006

Pulighe, G., \& Lupia, F. (2016). Mapping spatial patterns of urban agriculture in Rome (Italy) using Google Earth and web-mapping services. Land Use Policy, 59, 49-58. https://doi.org/10.1016/j.landusepol.2016.08.001

Saha, M., \& Eckelman, M. J. (2017). Growing fresh fruits and vegetables in an urban landscape: A geospatial assessment of ground level and rooftop urban agriculture potential in Boston, USA. Landscape and Urban Planning. vol 165, hal

$130-141$. https://doi.org/10.1016/j.landurbplan.2017.04.01 5

Manongga, D., Papilaya, S. dan Pandie, S. 2009. Sistem Informasi Geografis untuk Perjalanan Wisata di Kota Semarang. Jurnal Informatika. vol 10, hal 1-9

Wowor, Aneke. 2013. Pemanfaatan Aplikasi GIS untuk Pemetaan Potensi Pertanian di Kabupaten Minahasa Utara. Jurnal Teknik Informatika. vol 2(1), hal 1-9. 